TAPROBANICA, ISSN 1800-427X. June, 2014. Vol. 06, No. 01: pp. 56-58, 2 pls.

(C) Research Center for Climate Change, University of Indonesia, Depok, Indonesia

\& Taprobanica Private Limited, Homagama, Sri Lanka

http://www.sljol.info/index.php/tapro

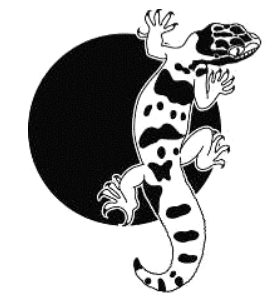

\section{On the herpetofauna in Loi Bher Wildlife Park, Rawalpindi, Pakistan}

The amphibian and reptilian species are considered excellent indicators of the relative amounts of microhabitats in any ecosystem, and features such as lotic water, permanent \& temporary lentic water, rock \& litter/debris vegetation, live vegetation, dead vegetation, plant species, and soil are important determinants of herpetofaunal abundance (Jones, 1980). The study on habitat preferences enables to comprehend ecological role and to predict the effect of habitat change on a species (Beard et al., 2003). Such studies are also very crucial for not only sustaining the species in captivity but also for designing their conservation strategies in the natural environment (Bousbouras \& Ioannidis, 1997). The available literature lacks any significant work on the abundance of herpetofauna and its association with habitats in various ecological zones of Pakistan. Khan (2006) has provided a general account of all known herpetofauna of Pakistan. Masroor (2011) has given an annotated checklist of herpetofauna of Margalla Hills National Park, Islamabad. Tabassum et al. (2011) have estimated population of skittering and bull-frogs in Rawal Lake, Islamabad. Thus far little effort has been expended on establishing a standardized monitoring program for herpetofauna mainly because of paucity of data pertaining to habitat requirements and partitioning.

The present study was designed to investigate habitat partitioning of herpetofauna at Loi Bher Wildlife Park (LBWP), Rawlpindi, Pakistan. It is located about $7 \mathrm{~km}$ in South-East of Islamabad city, spreading over an area of 359ha. The area is featured as humid subtropical, with long and hot summers; monsoon rains are short, while winter is mild, and wet. The park lies in a typical arid landscape, with hard substrate and scrub vegetation. The park gets moisture from River
Korang, a slow moving river, flowing most part of the year (Ahmad \& Ehsan, 2012; Ashraf et al., 2007). The habitat of the park can be assigned in to three major categories: open water habitat; marginal wetland type of habitat; and terrestrial habitat. The habitat variables recorded were categorized based on the type of substrate, availability of water, dominant vegetation and shelter sites (Table 1). We selected eight sampling sites, each with an area of 50ha, to record absence/presence of herpetofauna using area-constrained searches (Campbell \& Christman, 1982; Corn \& Bury, 1990; Fellers \& Freel, 1995; Heyer et al., 1994; Sutherland, 1996) and noted dominant vegetation. In total ten surveys from February 2010 through January 2011, during morning (07:00-09:00 h), afternoon (14:00-16:00 h) and evening time (20:00-22:00 h) were undertaken. Herpetofauna were identified by using Khan (2006) and Daniels (2002). To more objectively assess the association between habitat variables and the herpetofauna, we performed a multivariate ordination test; Principle Component Analysis (PCA). The two matrices containing species/habitat variables in columns and sites in rows were imported to PC-ORD and PCA was conducted using default settings. We conducted hierarchical clustering in XLSTAT using Euclidian distance and Ward's method to cluster sites with similar habitat settings. We also performed clustering on presence/absence data of species of amphibians and reptiles. In both instances, we used data matrix of dummy variables $(0,1)$ containing habitat variable/species in columns and sites in rows.

The park as a whole did not offer a variety of habitat nor a diverse herpetofauna. The three clusters generated by the cluster analysis of sampling sites based on habitat variables (Fig. 1) corresponded to the three clusters of herpetofauna species recorded from the sampling sites (Fig. 2). The group I included sampling sites 1,3 and 5 characterized by 
shelter sites (logs and stones), moist soil and open water with low abundance of Phragmites karka and Saccharum benghalense. The associated herpetofauna species included Lissemys punctata, Nilssonia gangetica, Pangshura smithii, Pangshura tecta, and Xenochrophis piscator. Group II included sampling sites 2, 4 and 6 characterized by hard substrate, crevices as shelter sites and were dominated by shrubs such as Lantana camara, Maytenus royaleanus and Ziziphus nummularia and trees such as Acacia modesta, Acaia nilotica, Morus nigra, and Prosopis juliflora. The associated herpetofauna species included Calotes versicolor, Echis carinatus, Hemidactylus brookii, Oligodon arnensis, and Varanus bengalensis. The group III encompassed sampling sites 7 and 8 characterized by wetland margins having some Phragmites karka and abundant Cynadon dactylon and logs as shelter sites. The associated herpetofauna species included Duttaphrynus melanostictus, Bufo stomaticus, Euphlyctis cyanophlyctis, Hoplobatrachus tigerinus, and Bungarus caerulus.

Table 1: Habitat components of each site at LBWP, (life form $=\mathrm{H}$, herb; G, grass; $\mathrm{S}$, shrub; $\mathrm{T}$, tree); (substrate = M, moist; L, loose; H, hard); (shelter sites $=\mathrm{L}, \operatorname{logs} ; \mathrm{C}$, crevices; $\mathrm{S}$, stones; R, rocks; $\mathrm{B}$, burrows).

\begin{tabular}{|c|c|c|c|c|c|}
\hline No & Dominant Vegetation & 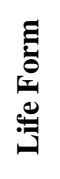 & 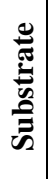 & 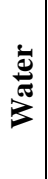 & 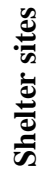 \\
\hline 1 & $\begin{array}{l}\text { Parthenium hysterophorus } \\
\text { Desmostachya bipinnata }\end{array}$ & HG & $\mathrm{M}$ & + & $\begin{array}{l}\mathrm{L} \\
\mathrm{C} \\
\mathrm{S}\end{array}$ \\
\hline 2 & $\begin{array}{l}\text { Lantana camara } \\
\text { Asparagus dumosus }\end{array}$ & $\mathrm{SH}$ & $\mathrm{H}$ & - & C \\
\hline 3 & $\begin{array}{l}\text { Cynodon dactylon } \\
\text { Desmostachya bipinnata }\end{array}$ & GG & $\mathrm{M}$ & + & $\begin{array}{l}\mathrm{L} \\
\mathrm{C} \\
\mathrm{S}\end{array}$ \\
\hline 4 & $\begin{array}{l}\text { Brachiaria ramosa } \\
\text { Malvastrum } \\
\text { coromandelianum }\end{array}$ & GH & $\mathrm{H}$ & - & $\mathrm{C}$ \\
\hline 5 & $\begin{array}{l}\text { Phragmites karka } \\
\text { Nasturtium officiniale }\end{array}$ & GH & $\mathrm{M}$ & + & $\begin{array}{l}\mathrm{L} \\
\mathrm{C} \\
\mathrm{S}\end{array}$ \\
\hline 6 & $\begin{array}{l}\text { Xanthium strumarium } \\
\text { Ziziphus nummularia }\end{array}$ & HS & $\mathrm{H}$ & - & C \\
\hline 7 & $\begin{array}{l}\text { Lantana camara } \\
\text { Maytenus royaleanus }\end{array}$ & ss & $\mathrm{L}$ & - & $\begin{array}{l}\mathrm{L} \\
\mathrm{R} \\
\mathrm{B}\end{array}$ \\
\hline 8 & $\begin{array}{l}\text { Cynodon dactylon } \\
\text { Morus nigra }\end{array}$ & GT & $\mathrm{L}$ & - & $\begin{array}{l}\mathrm{L} \\
\mathrm{R} \\
\mathrm{B}\end{array}$ \\
\hline
\end{tabular}

Principal Component Analysis (Fig. 3) revealed pronounced ordination of the sampling sites and herpetofauna species, and validated the results obtained from the cluster analysis. The PCA plot displays the separation in habitats of the recorded species on two axes in multivariate space. The first two axes explained $98 \%$ of the variation. The length of the arrow shows the rate of change in abundance in that direction. Stones and availability of water have an influence for combining the sites 1, 3 and 5 together while hard soil has its impact on sites $2,4,6$, and 8 . The first principal component axis appeared to be mainly related to shelter sites, water and vegetation. The logs, crevices, grasses, stones and water were located on the positive side of the axis I. The variables such as grasses and crevices influenced occurrence of Lissemys punctata, Nilssonia gangetica, Pangshura smithii, Pangshura tecta, and Xenochrophis piscator. The variables such as burrows, rocks, loose soil and shrubs were located on positive side of the axis II and had some influence on Platyceps ventromaculatus while herbs were located on negative side of axis II influencing occurrence of Calotes versicolor, Echis carinatus, Hemidactylus brookii, Hemidactylus flaviviridis, Oligodon arnensis, and Varanus bengalensis.

Available published literature showed similar habitat partitioning. The Common garden lizard (Calotes versicolor) was reported from shrubs and on trees (Bobrov, 1993); Duttaphrynus melanostictus and Bufo stomaticus from terrestrial habitats; Euphlyctis cyanophlyctis and Hoplobatrachus tigerinus near aquaticmargin, Varanus bengalensis in scrub forest or rocky biotope; Bungarus caeruleus and Echis carinatus in scrub and bordering agricultural fields while Pangshura tentoria, Nilssonia gangetica, Lissemys punctata, and Xenochropis piscator from wetlands (Srinivasulu \& Das, 2008). We observed Calotes versicolor frequently on Prosopis juliflora and on few occasions it was seen on the ground which upon approach immediately takes abode in grasses such as Cynadon dactylon. We also got the same habitat-species association except we recorded Bungarus caeruleus and Echis carinatus from rocky biotope. Murphy et al. (1999) reported Xenochrophis piscator uses multiple microhabitats and forage between terrestrial and aquatic microhabitats. We observed the species moving actively among 
the stones and swimming in the open water at night.

The land in the surroundings of the park is being developed into residential areas. The water in the wetland flows very slowly for most part of the year thereby encouraging algal growth. The addition of municipal waste further exacerbates the situation by increasing the organic material content. Further, the park receives a high influx of visitors. Hence, the herpetofauna species recorded from the park revealed high tolerance to land-use change, human intervention, anthropogenic activities and pollution. However, the present study dealt only with the presence/absence of species. It is suggested that detailed studies on the population to be carried out to see if the factors currently affecting the park have any influence on the herpetofauna.

\section{Acknowledgements}

We would like to thank Johan Van Rooijen and John Rudge for reviewing the manuscript.

\section{Literature cited}

Ahmad, S. S., and H. Ehsan, 2012. Analyzing the herbaceous flora of Loi Bher Wildlife Park under variable environmental stress. Pakistan Journal of Botany, 44: 11-14.

Ashraf, M., M. A. Kahlown, and A. Ashfaq, 2007. Impact of small dams on agriculture and groundwater development: a case study from Pakistan. Agricultural Water Management, 92: 90-98.

Beard, K. H., S. McCullough, and A. K. Eschtruth, 2003. Quantitative assessment of habitat preferences for the Puerto Rican terrestrial frog (Eleutherodactylus coqui). Journal of Herpetology, 37: 10-17.

Bobrov, V. V., 1993. Spatial organization of a tropical lizard community in a forested area in northern Vietnam. Herpetozoa, 6: 21-28.

Bousbouras, D., and Y. Ioannidis, 1997. The distribution and habitat preferences of the amphibians of Prespa National Park. Hydrobiologia, 351: 127-133.

Campbell, H. W., and S. P. Christman, 1982. Field techniques for herpetofaunal community analysis. In: N. J. Scott (Ed.). Herpetological communities: 193-200.
Corn, P. S., and R. B. Bury, 1990. Sampling methods for terrestrial amphibians and reptiles. U.S.D.A. Forest Service General Technical Report PNW-256: 34.

Fellers, G. M., and K. L. Freel, 1995. A standardized protocol for surveying aquatic amphibians. National Park Service Tech Report, NPS/WRUC/NRTR-95-01 (UC CPS TR \# 58), Washington, DC.

Heyer, W. R., M. A. Donnelly, R. W. McDiarmid, L. C. Hayek, and M. S. Foster, 1994. Measuring and monitoring biological diversity, Standard methods for amphibians. Smithsonian Institution Press, Washington: 363.

Jones, K. B., 1980. Amphibians and reptiles. In: Cooperrider, A. Y., R. J. Boyd, and H. R. Stuart (Eds.). Inventory and Monitoring of Wildlife Habitat. U.S. Department of the Interior, Bureau of Land Management, Denver, CO.:267-290.

Srinivasulu, C. and I. Das, 2008. The herpetofauna of Nallamala Hills, Eastern Ghats, India: An annotated checklist, with remarks on nomenclature, taxonomy, habitat use, adaptive types and biogeography. Asiatic Herpetological Research, 11: 110-131.

Sutherland, W. J. (Ed.)., 1996. Ecological Census Techniques: A Handbook. United Kingdom: Cambrige University Press, UK: 336.

Submitted: 23 Aug. 2012, Accepted: 17 May 2014 Section Editor: Gernot Vogel

$$
\begin{array}{r}
\text { M. Rais }{ }^{1,3}, \text { J. Rehman }^{1}, \text { S. Baloch } \\
\text { S. M. Ali }
\end{array}
$$

\footnotetext{
${ }^{1}$ Department of Wildlife Management, PMAS Arid Agriculture University Rawalpindi 46000, Pakistan

${ }^{2}$ Department of Environmental Sciences, Female Campus, International Islamic University, Islamabad, Pakistan

${ }^{3}$ E-mail: sahil@uaar.edu.pk
} 


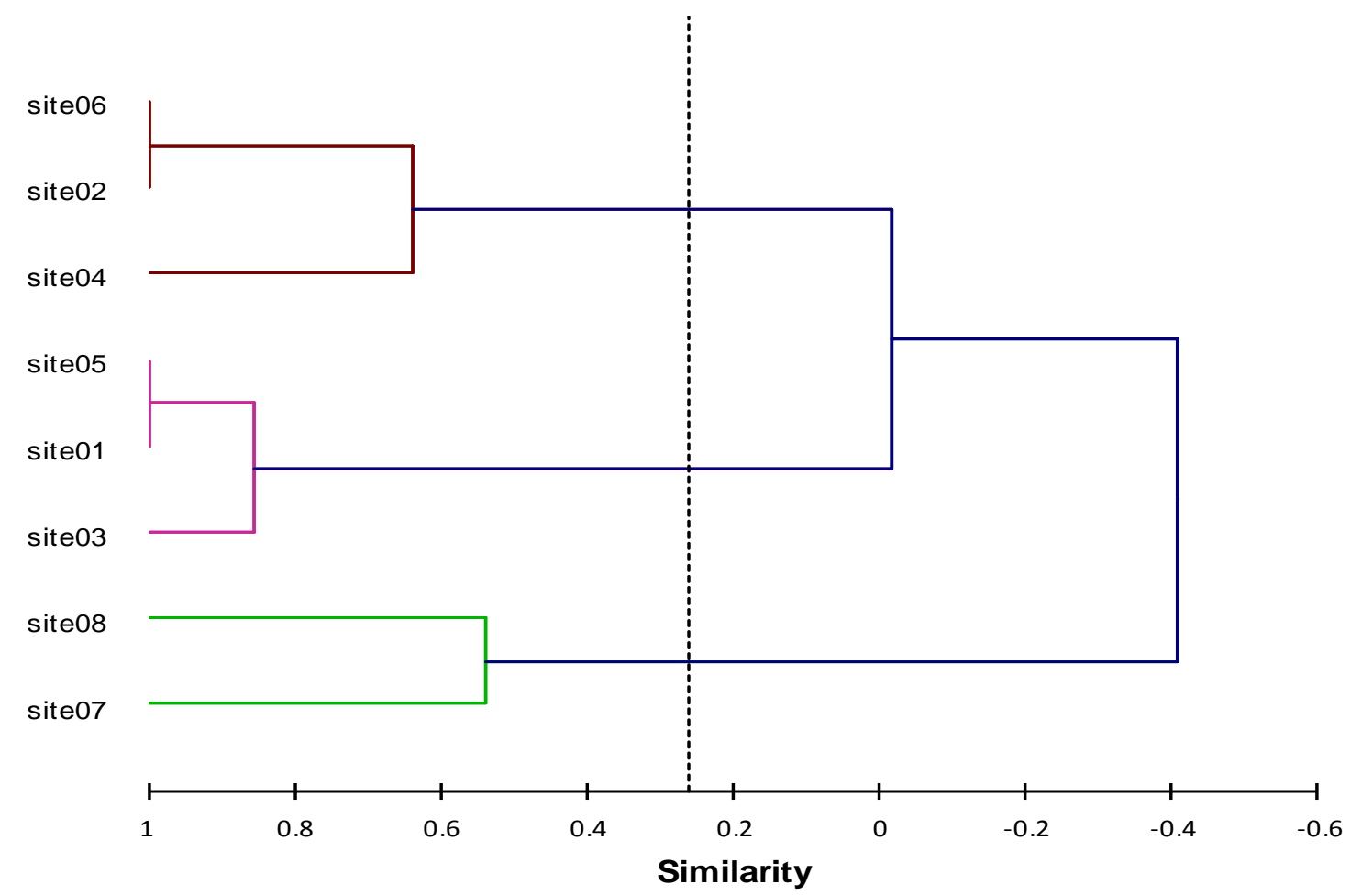

Fig. 1: Cluster analysis of sampling sites based on habitat variables; the dotted line represents the automatic truncation, leading to three groups or clusters.

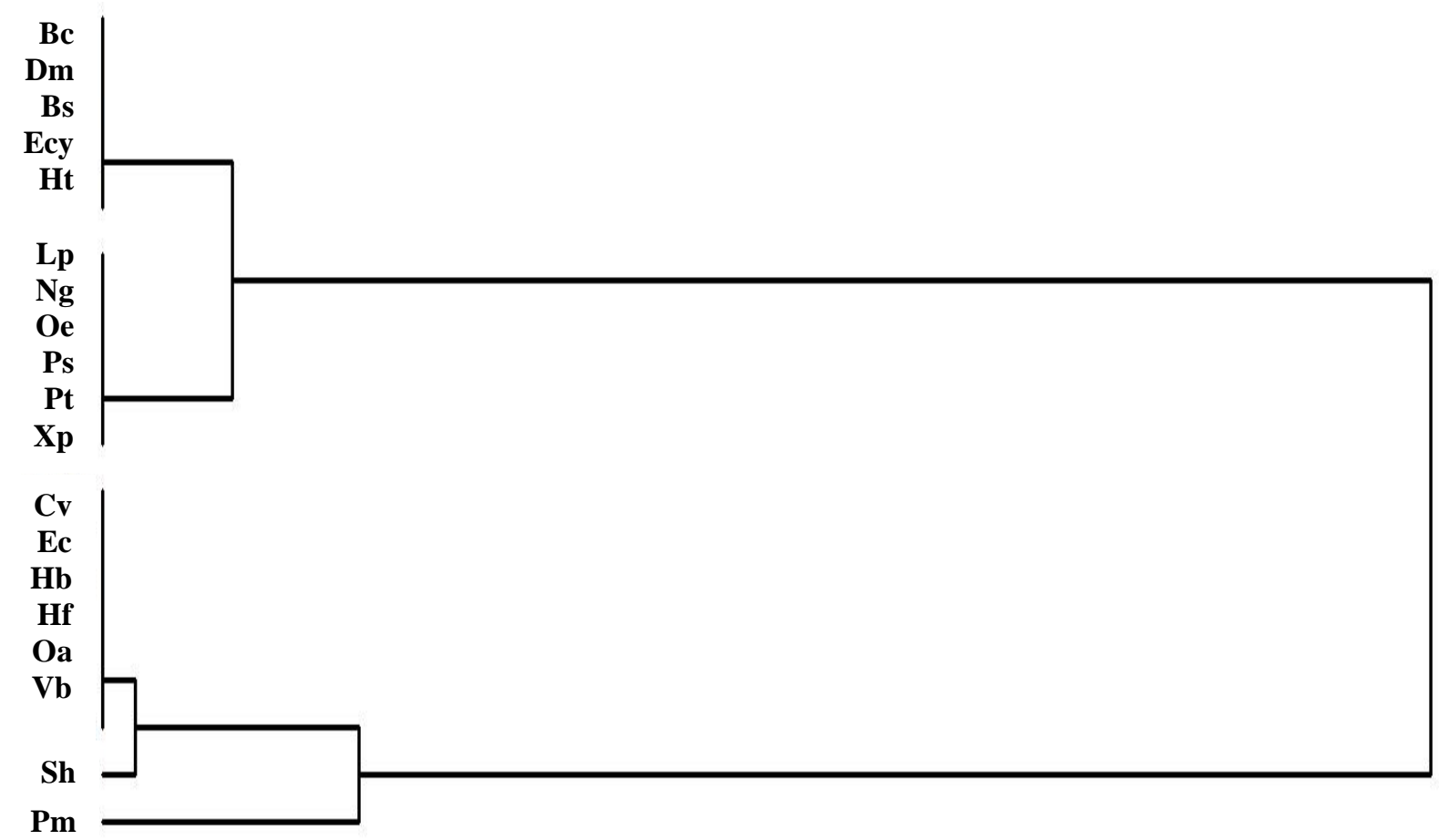

Figure 2: Cluster analysis of spatial organization of herpetofauna at LBWP; (for species abbreviations, follow figure 3 caption). 


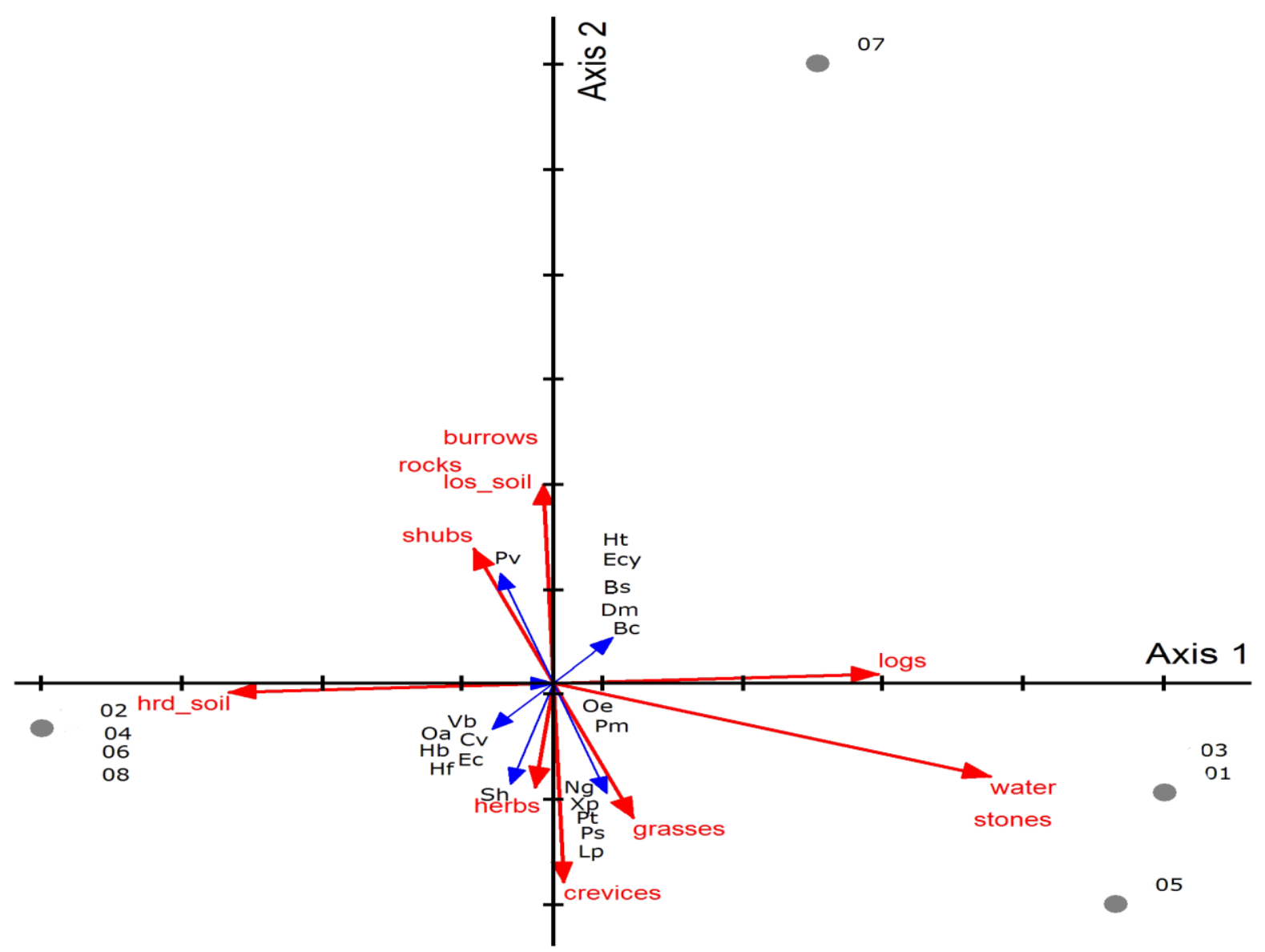

Fig. 3: PCA comparing matrices of structural habitat characteristics with the recorded species of herpetofauna plotted on principle axis 1 (Eigen value, 30.92; \% of variance, 88.05) and axis 2 (Eigen value, 3.60; \% of variance, 10.27); 1-8, sampling site; los_soil, loose soil and hrd_soil, hard Soil; Bc, Bungarus caerulus; Dm, Duttaphrynus melanostictus; Ds, Bufo stomaticus; Ecy, Euphlyctis cyanophlyctis; Ht, Hoplobatrachus tigerinus; Lp, Lissemys punctata; Ng, Nilssonia gangeticus; Oe, Ophisops jerdonii; Ps, Pangshura smithii; Pt, Pangshura tecta; Pm, Ptyas mucosus; $\mathrm{Pv}$, Platyceps ventromaculatus; Xp, Xenochrophis piscator; $\mathrm{Cv}$, Calotes versicolor; Ec, Echis carinatus; Hb, Hemidactylus brookii; Hf , Hemidactylus flaviviridis; Oa, Oligodon arnensis; Vb, Varanus bengalensis; and Sh, Saara hardwickii; Note: The vector lengths in the PCA plot are proportionate to the effect of variables on discriminating sightings of the species with long vectors denoting variables of great influence on the separation of points in multivariate space and small vectors denoting variables that had little influence. 